\title{
Contingency Valuation of Croatian Arboretum Opeka
}

\section{Stjepan Posavec}

University of Zagreb, Faculty of Forestry, Department of Forest Inventory and Management, Zagreb

Croatia

sposavec@sumfak.hr

\section{Karlo Beljan}

University of Zagreb,

Faculty of Forestry,

Department of Forest

Inventory and Management, Zagreb

Croatia

\section{Nina Herceg}

Kralja Tomislava 17 42220 Novi Marof Croatia

\section{Špela Pezdevšek Malovrh}

University of Ljubljana,

Biotechnical Faculty,

Department of Forestry

and Renewable Forest Resources, Ljubljana

Slovenia

\section{Abstract}

Background and purpose: Social aspects of forestry have always been an important factor of forest usage and management, and therefore have significant influence on its sustainability. Non-wood forest functions such as recreation, tourism, aesthetic and educational factors influence development of rural areas. Contingent valuation method has rarely been used for evaluation of protected forest areas. The aim of the article is to estimate the amount of money visitors are willing to pay for nature's resources preservation in the arboretum Opeka in the North-West Croatia.

Material and methods: Opeka Arboretum is situated in the Vinica municipality in northern Croatia. Located in a large park surrounding a manor, Opeka arboretum, with its 65 hectares is the largest of the three arboretums existing in Croatia today. The arboretum was founded in 1860 by the

\section{INTRODUCTION}

Forest Economics is a discipline that studies production, distribution, and consumption of forest products and services. It characterizes mental calculus of a decision maker, whether a private landowner or a policy maker, by focusing on the relationship between ends and scarce means (resources) that have alternative uses [1]. In other words, forest economics is a study of choices relating to forest conservation and management.

Natural resources are considered unique input factors; out of which many have features that make them similar to capital factors. Foremost, in order to be used for consumption or in the production process, the majority of natural resources must be separated [2]. Time is also an important precondition in analysis of natural resources use. It helps in distinguishing different types of resources.

Determining the total economic forest value, as well as the value of a particular function is needed
Count Marko Bombelles. Contingent valuation is a surveybased economic technique for the non-market valuation of resources, such as environmental preservation or the impact of contamination. It is also the approach that can generally be used to include what is usually referred to as the passive use component of the economic value of environmental goods.

Results and conclusion: Willingness to pay for visitor's use of the arboretum has been investigated using the survey and contingency valuation method on a sample of 53 respondents. Research results present high preference for arboretum benefits such as beauty of landscape, cultural and historical significance, recreation and health but low willingness to pay.

Keywords: contingency valuation, environmental economics, willingness to pay, arboretum, Opeka

for effective management of natural resources and better making of investment decisions in forestry [3]. Classical forest evaluation methods are based on calculation of growing stock value (stand) and land value. Quantitative inventory is conducted on stand level (forest unit), due to the heterogeneous characteristics based on stand quality, coverage, tree species etc. Some stands have different biological parameters and evaluation methods because of their different location [4].

The contingent valuation method (CV) approach uses surveys to directly measure people's willingness to pay (WTP) for nonmarket goods. The early CV studies focused on developing empirical estimates of theoretical welfare measures. Particularly concentrated on measuring the benefits of air quality regulations, although various methodological experiments were also undertaken [5-7]. According to Boyle, [8] the CV method is consistent with welfare economic theory and provides an empirical method that can capture nonuse values of environmental goods. A recent 
meta-analysis by Barrio et al. [9] examines how characteristics of the survey instrument, the sample, and the study area tend to influence CV estimates for forest services.

There is a lack of research regarding estimation of forest values with CV method in Croatia. Different environmental valuation methods were used to estimate the aesthetic value of coastal forests in Croatia to tourists. Results from a Contingent Valuation (CV) study of tourists' willingness-to-pay (WTP) for a hotel room with a view of coastal forests were compared to a Hedonic Price (HP) analysis of hotel room prices, and an Expert Assessment (EA) by hotel managers providing their best guess of the added value to a hotel room from a coastal forest view [10].

An economic analysis of a Coastal Forest Reconstruction and Protection Project in Croatia reveals the significance of environmental amenities provided by the forests to economic and social sectors. The assessment conducted in this study was carried out for fourteen sites that are proposed for the restoration. Estimates for the landscape values of restoration are based on the visitors' willingness to pay for the forested landscape (derived from contingent valuation studies) estimated at $\$ 1.50$ per visitor per day. Benefits from each site are then determined from the number of hotels beds which would benefit from the restoration. The results are adjusted for site specific factors, e.g. attractiveness of the locality [11].

Detailed review of the forest valuation literature provided different authors like Krieger et al. [12], Holgen et al. [13], and Mogas et al. [14] by approaching sources of value separately, some of which are dominated by the CV method. Methods which are today often used for environment valuation are classified as monetary methods [3].

The aim of the paper is to explore values of nature's resources provided to environmental service users by using the contingency valuation method. The research tries to identify arboretum visitor's preferences and attitudes towards the condition and appearance of arboretum.

The obtained results will help future development and protection of this cultural good and horticultural monument, which is in decay owing to insufficient investments.

The study investigated the determinants of stated WTP for access to forests for outdoor recreation and similar purposes.
Arboretum Opeka is an important biological and cultural-historical facility ruined because of the financing issues. Despite of the bad condition, arboretum attracts many visitors every year, which is one of the reasons for exploring the arboretum's social values. The paper was prepared in cooperation with Public Service for Management of Protected Nature's Resources of Varaždin County. The research results could be used for future management and investments in Arboretum.

\section{MATERIAL AND METHODS}

\section{Study area}

Arboretum Opeka is on the NW part of the Croatia, close to the city of Varaždin, at the area of 65 hectares. It is divided in two parts, lower plain land shaped in English style and upper, shaped like park-forest consisted of sessile oak (Quercus petraea (Matt.) Liebl.) and chestnut (Castanea sativa Mill.). On arboretum is also baroque castle Opeka which together with gardens and park-forest form three independent zones. The lake created during the soil digging for production of terracotta in former factory, is on the lower part of the Arboretum. The small island connected with the wooden bridge is in the middle of the lake. According to Potočić [15], arboretum is an independent space or part of the botanical garden where trees and coppice are cultivated for scientific, ornamental or silvicultural purposes.

Because of its artistic, scientific, educational, cultural-historical and other values arboretum was protected by Law of nature protection [16] in 1961 (in category of park architecture monument - arboretum). That monument of park architecture is defined as an artificially created space, individual tree or a group of trees that have aesthetical, artistic, cultural-historical, ecological or scientific value. Any kind of activities that could harm or change the protected values are not allowed (on the monument or in the nearest area). The complex was announced as protected cultural good in 2007. Because of favourable ecological conditions there are many protected species from Europe and other countries collected in the arboretum. There are more than 800 different tree species, scrubs, lianas and flowers [17].

\section{Contingency valuation}

The CV approach uses surveys to directly measure people's willingness to pay (WTP) for nonmarket goods. Contingent valuation is a survey-based economic technique for the valuation of non-market resources, such as environmental preservation or the impact of contamination. While these resources do give people 
utility, certain aspects do not have a market price as they are not directly sold - for example, people receive benefit from a beautiful view of a mountain, but it would be tough to evaluate it using price-based models. Contingent valuation survey is a technique used to measure these aspects. Contingent valuation is often referred to as a stated preference model, in contrast to a price-based revealed preference model. Both models are utility-based. Typically the survey asks how much money people would be willing to pay (or willing to accept) to maintain the existence of (or be compensated for the loss of) an environmental feature, such as biodiversity.

\section{Visitors Survey}

The studied group consisted of visitors of arboretum Opeka of all age groups. Face to face interviews were carried out in April and May 2012 during the weekends, working days (afternoon) and holidays. The assumption was that at those times the arboretum has the most visitors. In the survey the visitors were asked about a range of issues related to their visit to the arboretum Opeka and their willingness to pay.

Before asking the questions it was explained to the respondents that the research is being conducted by the Faculty of Forestry University of Zagreb with the aim of sociological valuation of Opeka arboretum. This was supported by a short text on history and significance of arboretum.

In the first part of the questionnaire were questions about motivation for visiting the arboretum and experience of the visit. The respondents evaluated separately the condition of the gardens, castle and the entire complex. The second part of the questionnaire contained specific questions related to contingent method, i.e. how much the visitors are ready to pay for the improvement of the services. The third part was related to the socio-demographics of the respondents. The sample size was 53 respondents.

\section{Statistical methods}

All the data in the research were first summarized by descriptive statistics, frequency distributions, and selected measures of location and dispersion (mean and standard deviation). The crosstabulation was used to assess the relationship between willingness to pay for complete protection and management of arboretum Opeka and visitor's income as the crosstabulation display in table the relationship between two categorical variables. The chi-square test (95\% significance interval) was used to determine whether there is a relationship between the variables WTP and income. Data analyses were conducted in SPSS 18.0.

\section{RESULTS AND DISCUSSION}

The largest part of respondents was in the age group $45-54$. Of the 53 visitors interviewed, $43.4 \%$ were male and $56.6 \%$ female distributed through all age groups. The majority of respondents (69.8\%) work in the services industry or in public service. More than half of the respondents (59\%) have a monthly income lower than $800 €$.

\section{Motivation for visiting the arboretum}

Motivation for visiting the arboretum is connected to visitor's experiences of previous visits, frequency of those visits and services offered by the arboretum.

Are you familiar with arboretum characteristics?

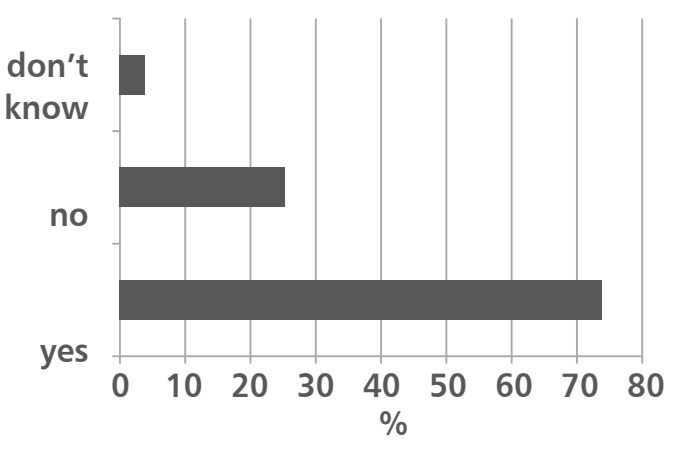

\section{FIGURE 1}

Familiarity with arboretum conditions

Visitor's familiarity with Arboretum is mostly based on previous visits to Opeka. Results show that $72 \%$ of respondents are familiar with conditions/ circumstances of Arboretum Opeka, while 25\% are not familiar with those conditions. Furthermore, $4 \%$ of respondents don't know arboretum well so they did not give an answer. The majority of respondents (78\%) answered that they visit arboretum once in a few months. Only $2 \%$ of visitors come to Opeka every day. Beauty of landscape is the most common reason for visiting arboretum. Almost half (48.5\%) of arboretum's visitors come mostly for enjoyment in the landscape, while other reasons include recreation, cultural and historical significance of the site. Only $8 \%$ of visitors use arboretum for health reasons.

\section{TABLE 1}

How visitors evaluate the arboretum's condition

\begin{tabular}{|c|c|c|c|}
\hline & Park & Castle & Together \\
\hline Average & 2.75 & 1.17 & 2.28 \\
\hline
\end{tabular}

Rating (1- very bad, 4-very good) 
Because of its cultural importance and biodiversity the park was awarded the highest value. As it can be seen from the table 1, Opeka arboretum presents a negative image to its visitors, the reasons for which are of financial nature, as there are insufficient funds for investing in the arboretums maintenance and forest management.

\section{Contingent valuation}

On average, the visitors are willing to pay $10.6 €$ for the complete protection and management of the arboretum. The cross tabulation showed (Table 2) that the visitors with lower income (less than $800 €$ ) are not willing to pay for arboretum's maintenance (43.5\%). While the visitors with higher income (more that $800 €$ ) are more willing to pay. $37.5 \%$ of visitors are willing to pay up to $10 €$ and $43.8 \%$ more than $10 €$. form of financial support to the arboretum. The visitors are willing to pay $2.6 €$ for the daily ticket.

The results show that the value of arboretum increases with the satisfaction of its visitors which is encouragement and guideline towards its future management, maintenance and adjustment of its offer to the needs of the visitors.

\section{CONCLUSIONS}

Through the research of social values of Opeka arboretum by using the contingency valuation method, useful results were obtained which could be of aid to the Public Service for Management of Protected Nature's Resources of Varaždin County in decision making processes regarding its maintenance and management. Besides identification of the

TABLE 2

Willingness to pay for protection and management of arboretum

\begin{tabular}{|c|c|c|c|c|}
\hline & \multicolumn{2}{|c|}{ Income } & \multirow{2}{*}{ Total (\%) } \\
\hline & & Less than $800 €(\%)$ & More than $800 €(\%)$ & \\
\hline \multirow{4}{*}{ Willingness to pay } & $0 €$ & 43.5 & 18.7 & 33.3 \\
\hline & $0.1-10 €$ & 26.1 & 37.5 & 30.8 \\
\hline & More than $10 €$ & 30.4 & 43.8 & 35.9 \\
\hline & Total & 100.0 & 100.0 & 100.0 \\
\hline
\end{tabular}

The Pearson chi-square test shows that there is no statistically significant relationship between variables $\left(\chi^{2}=2.596, p=0.273\right)$.

TABLE 3

Chi-Square Tests

\begin{tabular}{|l|c|c|c|}
\hline & Value & df & $\begin{array}{c}\text { Asymp. Sig. } \\
\text { (2-sided) }\end{array}$ \\
\hline Pearson Chi-Square & $2.596^{\mathrm{a}}$ & 2 & .273 \\
\hline Likelihood Ratio & 2.713 & 2 & .258 \\
\hline $\begin{array}{l}\text { Linear-by-Linear } \\
\text { Association }\end{array}$ & 1.924 & 1 & .165 \\
\hline N of Valid Cases & 39 & & \\
\hline
\end{tabular}

By asking the question about WTP in order to prevent conversion of the arboretum into a building site, the intention was to find out whether the visitors are willing to pay higher price in order to preserve this environmental good. On average they are willing to pay an $15 €$. The most of visitors (87\%) are against the conversion of arboretum to building site.

The most efficient method of collecting financial means would be through introduction of an entrance fee, as the visitors showed significant interest in this reasons for visiting arboretum, the profile of its visitors and their evaluation of its condition, significant information was obtained on the visitors' willingness to pay $10.6 €$ on the annual basis in order to provide for the protection and maintenance of the arboretum. It has been made clear that the visitors are not satisfied with the current condition and management of this protected area, and that there is demand for social forest services such as recreational activities, aesthetic and educational values which this forest is able to provide.

The contingency valuation method enables identification of environmental values which are difficult to measure as was shown in this research even on a small sample of respondents. The methods flexibility enables its wide application and adjustment to variety of problems connected to environmental services. Although this method has its limitations, it has been widely applied in many studies [18]. However, the method is rarely used in Croatia and mainly for evaluation of services tourists are willing to pay for a hotel visit or a protected nature site $[19,20]$.

Even though the data in this research was obtained from a relatively small sample, the results imply the need for further research of this area of forestry. 


\section{REFERENCES}

1. ROBBINS L 1932 An Essay on the Nature and Significance of Economic Science. Macmillan and Co., London, p 160

2. POSAVEC S, BELAN K, LOVRIĆ M 2011 Model of compensation payment to the owners on Natura 2000 forest sites. Glas šum pokuse (44): 19-28

3. FIGURIĆ M 1996 Uvod u ekonomiku šumskih resursa. Šumarski fakultet Sveučilišta u Zagrebu, Zagreb, p 244

4. POSAVEC S, ŠEGOTIĆ K, ČAKLOVIĆ L 2006 Selection of biological parameters in the evaluation of natural resources. Period biol 108 (6): 671-676

5. SCHULZE W D, D'ARGE R C, BROOKSHIRE D S 1981 Valuing Environmental Commodities: Some Recent Experiments. Land Econ 57 (2): 151-172

6. MAJID I, SINDEN J A, RANDALL A 1983 Benefit Evaluation of Increments to Existing Systems of Public Facilities. Land Econ 59 (4): 377-392

7. SELLAR C, STOLL J R, CHAVAS J P 1985 Validation of Empirical Measures of Welfare Change: A Comparison of Nonmarket Techniques. Land Econ 61 (2): 156-175

8. BOYLE K J 2003 A Premier of Non-Market Valuation, Contingent valuation in practice. In: Champ P A, Boyle K, Brown T C (eds) A Primeron Nonmarket Valuation. Kluwer, Dordrecht, pp 111-169

9. BARRIO M, LOUREIRO M L 2010 A meta-analysis of contingent valuation forest studies. Ecol Econ 69 (5):1023-1030

10. MARUŠIĆ Z, HORAK S, NAVRUD S 2005 The economic value of coastal forests for tourism: A comparative study of three valuation methods. Tourism 53 (2): 41-5

11. HORAK S 1998 The value of forests for coastal tourism in southern Croatia. Tourism (46) 2, 59-74
12. KRIEGER D 2001 Economic Value of Forest Ecosystems. The Wilderness Society, Washington, DC, p 40

13. HOLGÉN P, MATTSSON L, LI C Z 2000 Recreation values of boreal forest stand types and landscapes resulting from different silvicultural systems: an economic analysis. $\square$ Environ Manage 60 (2): 173-180

14. MOGAS J, RIERA P, BENNETT J W 2006 A comparison of contingent valuation and choice modelling with secondorder interactions. J Forest Econ 12 (1): 5-30

15. FIGURIĆ M 1996 Uvod u ekonomiku šumskih resursa. Šumarski fakultet, Sveučilište u Zagrebu, Zagreb, p 244

16. РОтОČı́́ Z 1980 Šumarska enciklopedija 1 A-Grad. Jugoslavenski leksikografski zavod, Zagreb, p 727

17. Zakon o zaštiti prirode (Official Gazette No. 70/2005, $139 / 2008)$

18. LADIĆ V 2012 Destination management and destination managing problems -example Vinica County. Interdiscipl manage research (VIII) 167-178

19. DUBERSTEIN J N, DESTEIGUER J E 2003 Contingent valuation and watershed management: a review of past uses and possible future applications. Proceedings of the First Interagency Conference on Research in the Watersheds, Benson, Arizona 749-753

20. WEBER S, HORAK S, MARUSIC Z 2002 Valuation of environmental assets: A case of Croatian coastal forests. Tourism Review 57 (1-2): 22-28

21. PAGIOLA S 1999 Valuing the Benefits of Investments in Cultural Heritage: The Historic Core of Split. Environment Department, The World Bank, Washington D.C. Paper presented at the World Bank Economists' Forum Alexandria, May 3-4 